\title{
Symposium on the philosophy of social and economic human rights
}

GUEST EDITED BY JULIO MONTERO 


\title{
The Philosophy of Social and Economic Human Rights
}

\author{
JULIO MONTERO \\ National Research Council of Argentina
}

The essays included in this volume are the result of a series of workshops organized by the United Kingdom-Latin America Network for Political Philosophy (UKLAPPN). The Network is sponsored by the British Academy of the United Kingdom and brings together academics from Argentina, Brazil, Chile, Colombia, Costa Rica, Mexico, Spain and the United Kingdom, who work in the field of contemporary political philosophy. As the title suggests, the main topic the volume addresses has to do with the nature, justification and implementation of socioeconomic human rights.

The normative relevance of socioeconomic human rights cannot be overlooked. According to the World Bank, 736 million people are situated below the poverty line of USD 1,90 per day and many of them die every year due to poverty-related causes (World Bank 2015). Severe poverty is thus one the most serious threats to human dignity of our time and the aim of socioeconomic human rights is precisely to conquer that threat.

International human rights law proclaims a wide array of socioeconomic rights, including rights to nutritious food, shelter, medical care, housing, education and social security (UN 1966). In the academic literature, there is some consensus that the fulfillment of these rights is essential if we want individuals to flourish as human persons. The reasonable assumption underpinning this view is that someone who is starving, illiterate or seriously ill becomes materially unable to make a valuable use of her freedoms and to lead a distinctively human life. So if we think that individuals have a fundamental right to develop their agency, we have decisive moral reasons to care about the satisfaction of their socioeconomic needs.

In spite of this consensus, there are also deep controversies about the normative justification of socioeconomic human rights. Some think that they are not genuine human rights because they are not universal: individuals can only claim them against modern political institutions and they would have no clear addresses in alternative scenarios. Instead, other authors insist that the list of socioeconomic rights proclaimed by current instruments is too demanding. In their opinion, people may have a human 
right to the resources they need for subsistence but they should not be recognized rights to the highest attainable standard of physical and mental health, free higher education, maternity leave or periodic holidays with pay (UN 1966). International instruments may have gone too far by placing societies under extremely burdensome or even unfeasible obligations. Finally, some liberal theorists argue that socioeconomic rights are secondary and less important than other categories of rights.

From a legal point of view, socioeconomic human rights enjoy the same status as civil and political ones. As the 1993 Vienna Declaration sustains, all human rights are indivisible, interdependent and equally important (UN 1993). In consequence, governments cannot pick and choose; they have a strict legal obligation to satisfy all our human rights at once. However, there are a number of crucial theoretical issues that must be urgently addressed if we want socioeconomic human rights to live up to their aspirations. Fundamentally, this is because international instruments provide no clear guidelines as to what States must do in order to honor their responsibilities in this respect. The 1966 International Covenant on Economic, Social and Cultural Rights defines its party's obligations in the following terms:

"Each State Party to the present Covenant undertakes to take steps, individually and through international assistance and cooperation, especially economic and technical, to the maximum of its available resources, with a view to achieving progressively, the full realization of the rights recognized in the present Covenant by all appropriate means, including particularly the adoption of legislative measures" (UN 1966, Article 2).

The evident problem with this key article is that the idea of progressive realization up to the maximum of available resources is extremely opaque. What are the resources available to a state? Does this clause only refer to its annual budget or it also includes all the resources governments could potentially collect through more progressive fiscal schemes and the full use of their natural resources? In practice, this vague language became a major obstacle for the effective realization of socioeconomic human rights as it makes almost impossible to decide when states have done enough to honor their commitments under the Covenant.

In a number of additional documents, the UN Committee on Economic, Social and Cultural Rights tried to specify the extent of states' obligations. In its General Comment 3 (1991), it establishes the existence of a "minimum core obligation" to ensure the satisfaction minimum essential levels of 
each of the rights:

"Thus, for example, a State party in which any significant number of individuals is deprived of essential foodstuffs, of essential primary health care, of basic shelter and housing, or of the most basic forms of education is, prima facie, failing to discharge its obligations under the Covenant. If the Covenant were to be read in such a way as not to establish such a minimum core obligation, it would be largely deprived of its raison d'être" (\#10).

Nevertheless, the notion of a "minimum core" is once more presented as dependent on the availability of resources:

"By the same token, it must be noted that any assessment as to whether a State has discharged its minimum core obligation must also take account of resource constraints applying within the country concerned" (\#10).

Finally, the Committee's analysis of the clause of "progressive realization" is considerably abstract and offers no operative orientation as to how to make sense of such requirement:

"It thus imposes an obligation to move as expeditiously and effectively as possible towards that goal. Moreover, any deliberately retrogressive measures in that regard would require the most careful consideration and would need to be fully justified by reference to the totality of the rights provided for in the Covenant and in the context of the full use of the maximum available resources" (\#9).

Unfortunately, the Committee never spells out what may count as a legitimate reason to postpone the satisfaction of socioeconomic rights or to justify the adoption of retrogressive measures.

In the specialized literature there is also an intense ongoing debate about the judicial enforcement of socioeconomic rights. Many authors argue that courts lack the legitimacy and the technical expertise required to make decisions about the allocation of scarce resources. Their claim is that socioeconomic human rights are not rights in the technical sense; they should rather be regarded as non-justiciable standards that governments must observe when designing their public policies and economic plans.

In recent years courts have developed some interesting strategies to deal with the difficulties that motivate these objections. In its influential sentence Government of the Republic of South Africa vs. Grootboom and Others, the Supreme Court of South Africa sustained that the housing program implemented by the local government of Cape Town was unsatisfactory (Constitutional Court of South Africa 2000). Its main 
argument was that while the government was investing a significant amount of resources in the program, the plan included no special measures to address the situation of those people who lacked even a precarious shelter for their families. Two aspects of the sentence make it particularly interesting. First, the Court recognizes that resources are limited and that judges have no authority to make decisions about their allocation. Second, the sentence does not order the government to provide any particular individual with immediate access to housing, but simply insists that the Executive should develop an alternative program that incorporates its recommendations.

The Grootboom sentence is certainly innovative. It shows that courts have some promissory resources to enforce the satisfaction of socioeconomic rights without invading the competences of democratic institutions. Yet, many critics object that the strategy adopted by the Court was too weak both because it established no clear standards for policy makers and because it failed to provide immediate relief to thousands of people living in miserable conditions.

As we see, socioeconomic human rights raise a number of questions of critical import for human rights theory and practice: what concrete measures must nations undertake to fulfill the socioeconomic rights of their inhabitants? When can a state legitimately claim that it is promoting their satisfaction up the maximum of its available resources? To what extent can their effective implementation be monitored by courts and what specific judicial techniques should they apply when supervising the conduct of governments? Can courts force elected functionaries to advance certain public policies instead of the plans supported by the people through electoral processes? Do they have the authority and skills to supervise the social programs chosen by democratic governments?

The essays in this volume explore some of these issues from a philosophical perspective. Mariano Garreta Leclercq argues against the constitutionalization and judicial implementation of socioeconomic human rights. In his view, when courts or expert committees unilaterally implement complex economic plans that are not approved through democratic mechanisms, they undermine the autonomy of the citizenry. This conclusion is backed by three general assumptions. The first one claims that there are deep controversies about the kinds of policies that could maximize the satisfaction of socioeconomic rights; the second one asserts that if those policies go wrong they could impose significant costs on the population and may even have a negative impact on the satisfaction of the essential needs of thousands of individuals; and the third assumption claims that treating persons as fully autonomous agents implies refraining 
from imposing risks on them, unless the potential victims have freely agreed to undertake those risks. As a result, it is up to the people to decide what concrete measures to implement in order to bring about the satisfaction of socioeconomic human rights.

The essays by Eduardo Rivera López and Saladin Mackled-García investigate the normative structure of socioeconomic rights and human rights in general. Eduardo Rivera López claims that socioeconomic rights differ from classical liberal rights in a relevant aspect. The normative core of liberal rights is composed by "deontological constraints" not to treat people in certain ways. In this sense, the government cannot infringe the freedom of expression of an individual just by arguing that this will maximize the overall satisfaction of that same right. By contrast, socioeconomic rights are sensitive to aggregative considerations: governments may legitimately refuse to satisfy my right to an adequate diet if this implies that more people will have access to nutritious food in the immediate future. According to the author, this conceptual asymmetry between liberty rights and socioeconomic rights has important implications in terms of their enforcement by courts. In essence, while judges can protect individuals from discriminatory policies or order that some particular individuals be granted access to certain goods or services, they should refrain from sanctioning or recommending theimplementation of specific public policies aimed at maximizing the overall fulfillment of socioeconomic rights.

In turn, Saladin Meckled-García sustains that all categories of human rights involve two distinct kinds of obligations: "decisive obligations" and "weighting obligations". Decisive obligations are obligations not to take certain considerations into account when we decide how to treat an individual. So governments have a decisive obligation not to curtail people's access to certain public services or freedoms based on their gender, religion or ethnic origin. On the other hand, weighting obligations are obligations to give a fair weight to the needs and interests of separate persons. For example, when deciding what to do in order to promote my right to medical care, the government must balance my interest in enjoying that service versus the interests of other members of society in not paying higher taxes. The conclusion of the paper is that because human rights cannot be reduced to purely decisive obligations but also involve weighting ones, then any plausible account of human rights must include concrete principles as to how burdens and benefits must be distributed among members of a human community. Otherwise, the view would be seriously incomplete as it would fail to guide the action of political institutions.

Finally, Leticia Morales develops an original argument in favor of 
adopting a universal basic income scheme that allows people to satisfy their most essential needs. Her main ambition is to show that this kind of policy is valuable and morally mandatory not because it promotes the freedom of individuals, but because it improves the legitimacy of democratic institutions. The reasonable assumption that underlies this claim is that poverty constitutes a major obstacle to political participation and seriously discourages it. As a result, the implementation of a basic income scheme is not only a plausible strategy to advance the fulfillment of socioeconomic rights; it is also an integral component of a well-ordered democratic society.

In sum, the essays in this volume offer a comprehensive introduction to the philosophy of socioeconomic human rights and try to come up with concrete answers to some of the most important questions they raise. Our hope is that these contributions will stimulate the debate about their nature and precise implications and ultimately contribute to their universal realization.

\section{BIBLIOGRAPHY}

Constitutional Court of South Africa, 2000: Government of the Republic of South Africa and others v Grootboom and others (CCT11/00) [2000] ZACC 19; 2001 (1) SA 46; 2000 (11) BCLR 1169 (4 October 2000), URL = < $\underline{\text { http://www.saflii.org/za/ }}$ cases/ZACC/2000/19.html>.

UN, 1993: Vienna Declaration and Programme of Action, URL $=<$ https://www. ohchr.org/en/professionalinterest/pages/vienna.aspx $>$.

UN, 1966: International Covenant on Economic, Social and Cultural Rights, URL = $<$ https://www.ohchr.org/en/professionalinterest/pages/cescr.aspx $>$.

World Bank, 2015: “Poverty Overview”, URL = <https://www.worldbank.org/en/ topic/poverty/overview>.

UN Committee on Economic, Social and Cultural Rights, 1991 General Comment 3: The nature of states parties obligations, $\mathrm{URL}=<$ https://tbinternet.ohchr.org/layouts/treatybodyexternal/TBSearch. aspx?Lang=en \&TreatyID=9\&DocTypeID $=11>$. 